\title{
Analisis Kualitas Sistem Knowledge Management Metode Quality Function Deployment (Studi kasus: PT. Pupuk Sriwidjaja Palembang)
}

\author{
Yolita Lara Sari, Rusmala Santi, Irfan Dwi Jaya
}

\begin{abstract}
Knowledge management system is a system used by permanent employees of PT. Pupuk Sriwidjaja Palembang which aims to accommodate all the knowledge or work experience known to all employees at PT. Sriwidjaja Palembang Fertilizer. In this study there are some problems such as material shared by the admin such as videos, modules and other material that cannot be downloaded by users or users, there is no menu to connect to admin or system users, when the user or user shares learning material or work experience there is no notification directly to the system whether rejected or approved by the admin, there is no menu that can help beginners who are first using the knowledge management system. The purpose of this research is to analyze the quality level of knowledge management system services and how to improve the quality of knowledge management system services by utilizing the Quality Function Deployment method. to identify by distributing to respondents who were processed using Quality Function Deployment (QFD). The results of the distribution of questionnaires get a value of 3,764 with a low category which means it needs to be improved and processing in the QFD method in the House of Quality matrix there are $\mathbf{1 6}$ technical responses as a solution to improve service quality. Priority determination is obtained from calculating the relationship between user desires and technical responses then used to determine the priority of improvements that will be applied first.
\end{abstract}

Index Terms - Knowledge Management; Quality; Quality Function Deployment (QFD).

Abstrak-- Sistem knowledge management merupakan sistem yang digunakan oleh para pegawai tetap PT.Pupuk Sriwidjaja Palembang yang bertujuan untuk menampung semua ilmu pengetahuan atau pengalaman kerja yang diketahui oleh semua pegawai yang ada pada PT. Pupuk Sriwidjaja Palembang. Pada penelitian ini terdapat beberapa permasalahan seperti materi yang dibagikan oleh admin seperti video, modul dan materi lainnya tidak dapat didonwload oleh pengguna atau user, belum terdapat menu untuk terhubung keadmin atau

Yolita Lara Sari, Sistem Informasi, Universitas Islam Negeri Raden Fatah Palembang; email: yolitalaras@ gmail.com

Rusmala Santi, Sistem Informasi, Universitas Islam Negeri Raden Fatah Palembang; email: rusmalasanti uin@ radenfatah.ac.id

Irfan Dwi Jaya, Sistem Informasi, Universitas Islam Negeri Raden Fatah Palembang; email: irfan_dj@radenfatah.ac.id kepengguna sistem, ketika pengguna atau user membagikan materi pembelajaran atau pengalaman bekerja tidak ada pemberitahuan langsung kesistem apakah ditolak atau disetujui oleh admin, belum terdapat menu yang dapat membantu pemula yang baru pertama kali menggunakan sistem knowledge management. Adapun tujuan dari penelitian ini untuk menganalisis tingkat kualitas layanan sistem knowledge management dan bagaimana cara meningkatkan kualitas layanan sistem knowledge management dengan memanfaatkan metode Quality Function Deployment. untuk mengenalisa dengan melakukan penyebaran kepada responden yang diproses dengan menggunakan Quality Function Deployment (QFD). Hasil dari penyebaran kuesioner mendapatkan nilai sebesar 3,764 dengan kategori rendah yang artinya perlu diperbaiki dan pengolahan dalam metode QFD pada matrik House Of Quality terdapat 16 respon teknik sebagai solusi perbaikan kualitas layanan. penentuan prioritas didapat dari perhitungan hubungan antara keinginan pengguna dengan respon teknik kemudian digunakan untuk menentukan prioritas perbaikan yang akan diterapkan terlebih dahulu.

Kata Kunci- Knowledge Management, Kualitas, Quality Function Deployment (QFD)

\section{Pendahuluan}

Cara terbaik untuk mempertahankan pengetahuan yang berharga adalah dengan mengidentifikasi aset intelektual dan kemudian memastikan bahwa bahan warisan diproduksi dan kemudian disimpan sedemikian rupa untuk membuat pengambilan di masa depan dan digunakan kembali semudah mungkin [2]. Knowledge Management adalah suatu fungsi yang membentuk, mengidentifikasi dan mengelola penetahuan organanisasi untuk keuntungan jangka panjang [5] dan juga merupakan suatu praktik terbaik untuk mendapakan pengalaman bekerja bagi karyawan sehingga perusahaan dapat menghemat waktu dan biaya.

Metode Quality Function Deployment (QFD) alasan menggunakan metode tersebut karena metode tersebut mendengarkan suara atau kebutuhan pengguna atau user, jadi ketika peneliti menganalisis kualitas layanan sistem knowledge management menganalisis langsung dari suara atau tanggapan dari pengguna atau user. Untuk variabel pada penelitian menggunakan 
variabel Parasuraman untuk pembuatan kuesionernya sama seperti penelitian Wiyogo, fakultas teknik, universitas brawijaya Malang (2013) yang berjudul “integrasi Servqual dan Quality Function Deployment untuk pengukuran kualitas layanan (studi kasus: program studi pendidikan teknik mesin, universitas palangkaraya)". Alasan mengapa peneliti menggunakan variabel Parasuraman karena [2] yang mengatakan Servqual dapat digunakan pada rumah kualitas untuk mengevaluasi layanan organisasi berdasarkan kebutuhan pengguna.

Penerapan sistem knowledge management PT. Pupuk Sriwidjaja Palembang telah berjalan selama 10 tahun, namun dengan berkembanganya teknologi pada sistem knowledge management mereka melakukan pengembangan pada sistem tersebut. Memperbaiki kendala-kendala pada sistem yang sebelumnya terdapat kendala pada penerapan sistem knowladge management seperti materi yang dibagikan oleh admin seperti video, modul dan materi lainnya tidak dapat didonwload oleh pengguna atau user, belom terdapat menu untuk terhubung keadmin atau kepengguna sistem, ketika pengguna atau user membagikan materi pembelajaran atau pengalaman bekerja tidak ada pemberitahuan langsung kesistem apakah ditolak atau disetujui oleh admin, belum terdapat menu yang dapat membantu pemula yang baru pertama kali menggunakan sistem knowledge management. Untuk permasalahan tersebut maka dilakukan penelitian dengan memanfaatkan metode Quality Function Deployment untuk meningkatkan kuliatas layanan sistem knowledge management PT.Pupuk Sriwidjaja Palembang [Andri, Hasil Wawancara, 06 Maret 2019].

Berdasarkan permasalahan yang terdapat diatas maka penelitian ini mengangkat judul skripsi "Analisis Kualitas Sistem Knowledge Management Menggunakan Metode Quality Function Deployment (Studi Kasus: PT. Pupuk Sriwidjaja Palembang

\section{LANDASAN TEORI}

\subsection{Kualitas Layanan}

Kualitas layanan merupakan seberapa bagus tingkat layanan yang diberikan mampu sesuai dengan ekspentasi pengguna [9] dan juga merupakan tingkay kualitas dari sebuah layanan dapat dilihat dari sebagiamana layanan tersebut dapat memberikan layanan yang sesuai dengan kebutuhan pengguna.

Berdasarkan penjelasan diatas menurut para ahli dapat disimpulkan bahwa kualitas layanan merupakan sebuah tingkat keunggulan yang merupakan output yang tidak berbentuk fisik yang mempunyai manfaat bagi pengguna dan tingkat tinggi rendahnya berdasar pada harapan pengguna.

\subsection{Knowledge Manageent}

Manajemen pengetahuan (KM) pada awalnya didefinisikan sebagai proses penerapan pendekatan sistematis untuk menangkap, struktur, manajemen, dan penyebaran pengetahuan di seluruh organisasi untuk bekerja lebih cepat, menggunakan kembali praktik terbaik, dan mengurangi pengerjaan ulang yang mahal dari proyek ke proyek [3] dan juga merupakan suatu tehnik yang dilakukan perusahaan untuk mengoptimalkan kinerja semua karyawan dengan cara menyebarkan pengetahuan atau memberikan contok tehnik praktik kerja terbaik sehingga memudahkan karyawan dalam melakukan pekerjaannya.

Nonaka dan Takeuchi menggambarkan empat mode konversi, yang berasal dari kemungkinan pertukaran antara dua tipe pengetahuan pada gambar berikut:

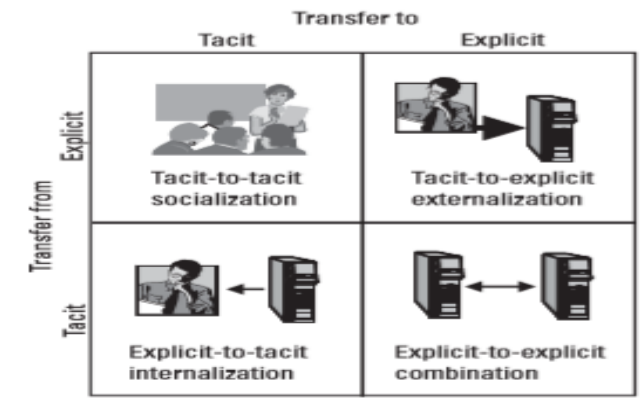

Gambar 1. Empat Model Konversi Knowledge Seci Process

\subsection{Quality Function Deployment (QFD)}

Quality Functin Deployment (QFD) didefinisikan sebagai metode perencanaan dan pengembangan suatu produk atau layanan yang memungkinakan tim peneliti untuk membuat spesifikasi yang tepat dari kebutuhan dan persyaratan pelanggan, kemudian menterjemahkannya kedalam parameter produk atau layanan, komponen-komponennya, serta aspek-aspke dari proses produksi [7] dan juga merupakan suatu metode yang melakukan proses pengembangan dengan menentukan kebutuhan pengguna sesuai dengan yang dibutuhakan dalam suatu sistem tersebut.

Berdasarkan kesimpulan diatas peneliti menyimpulkan bahwa Quality Functin Deployment (QFD) merupaka suatu metode yang dapat membantu peneliti untuk melakukan pengembangan dengan menyesuaikan dengan kebutuhan pengguna dan diterjemahkan kedalam bahasa teknik.

\subsection{Struktur dan Proses Quality Function Deployment}

House Of Quality (HOQ) merupakan alat yang digunakan dari proses Quality Function Deployment (QFD) yang menyajikan sebuah matrik perencanaan yang menghubungkan keinginan pelanggan atau kebutuhan pelanggan dengan bagaimanan perusahaan melakukan respon teknik untuk memenuhi kebutuhan pelanggan.

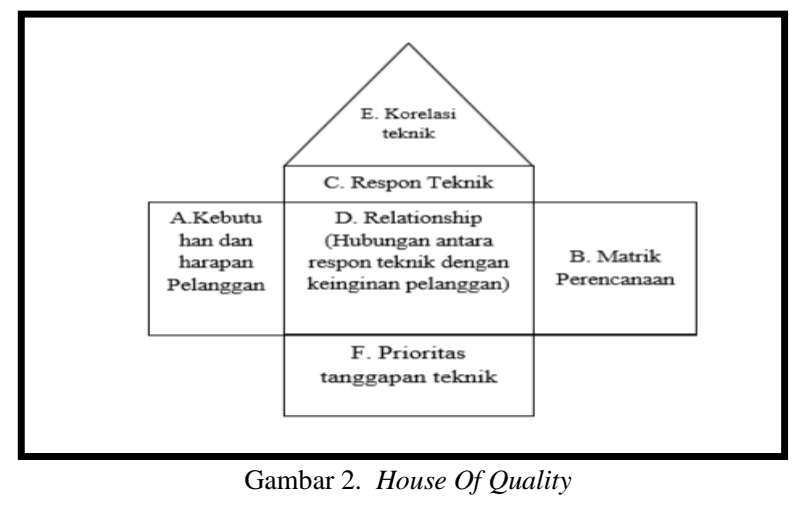


1. Kebutuhan dan harapan pelanggan (A), yang berisi sebuah data dari hasil penelitian tentang the whats dari keinginan dan kebutuhan pengguna.

2. Matrik Perencanaan (B), merupakan data yang mengidentifikasikan kepentingan dari kebutuhan pengguna dan harapan pengguna (A).

3. Respon teknik (C) ata yang disebut The Hows, fungsinya untuk menjawab kebutuhan dan harapan pelanggan (The Whats) yang dikembangkan dalam bahasa teknik perusahaan.

4. Relationship (D), berisi penilaian kekuatan korelasi antara elemen dari respon teknik yang ada pada The Hows (C) dengan setiap keinginan dan kebutuhan pelanggan yang ada pada The Whats (A).

5. Korelasi teknik (E), merupakan korelasi antar respon teknik satu dengan respon teknik yang lain terdapat dalam matrik (C).

6. Bagian (F), berisi urutan prioritas dan target kinerja teknik jasa [1].

\section{METODE PENELITIAN}

\subsection{Metode Penelitian}

Metode penelitian pada penelitian ini adalah penelitian deskriptif. Metode penelitian deskriptif adalah metode penelitian yang digunakan untuk mengetahui nilai variabel mandiri, baik hanya pada satu variabel atau lebih (variabel yang berdiri sendiri) tanpa membuat perbandingan dan menghubungkan variabel itu dengan variabel yang lain.

\subsection{Populasi dan Sampel}

Populasi dari penelitian ini terdiri dari admin sistem dan pegawai, dapat dilihat dari tabel berikut:

\begin{tabular}{|r|c|c|}
\hline Tabel 1. Data Populasi \\
\hline No. & Populasi & $\begin{array}{l}\text { Jumlah } \\
\text { Populasi }\end{array}$ \\
\hline 1. & $\begin{array}{l}\text { Admin } \\
\text { Sistem }\end{array}$ & 4 \\
\hline 2. & Pegawai & 1.796 \\
\hline \multicolumn{2}{|c|}{ Total Populasi } & 1.800 \\
\hline
\end{tabular}

Populasi yang diambil oleh peneliti pada PT. Pupuk Sriwidjaja terbagi menjadi 2 yaitu Admin dan Pegawai. Responden pada penelitian ini untuk jumlah admin 4 orang dan untuk jumlah pegawai 1796 orang, populasi keseluruhan diambil dari 1800 pegawai dan admin.

Alasan mengapa peneliti menggunakan sampel yaitu karena populasi sedemikian banyak sehinggga sulit untuk meneliti keseluruhan elemen, keterbatasan waktu, biaya penelitian dan sumber daya manusia.

$\mathrm{n}=\frac{\mathrm{N}}{\mathrm{N} \cdot \mathrm{e}^{2}+1}$

$\mathrm{n}=\frac{1800}{1800 \cdot 0,05^{2}+1}$

$\mathrm{n}=\frac{1800}{5,5}$

$\mathrm{n}=327$

Berdasarkan perhitungan menggunakan rumus slovin sampel didapat sebanyak 327 responden terdiri dari admin dan pegawai PT.Pupuk Sriwidjaja
Palembang yang meliputi pengguna aktif dan pasif sistem knowledge managemement PT. Pupuk Sriwidjaja Palembang.

3.3 Variabel Penelitian

Sesuai dengan masalah dan tujuan penelitian, variabel penelitian ini terdiri variabel. Variabel dapat dilihat pada table 2 berikut:

Tabel 2. Variabel Penelitian

\begin{tabular}{|l|l|}
\hline \multicolumn{1}{|c|}{ Variabel } & \multicolumn{1}{c|}{ Dimensi } \\
\hline \multirow{4}{*}{$\begin{array}{l}\text { Kualitas } \\
\text { Layanan }\end{array}$} & Efficiency \\
\cline { 2 - 2 } & System availability \\
\cline { 2 - 2 } & Fulfillment \\
\cline { 2 - 2 } & Privacy \\
\cline { 2 - 2 } & Responsiveness \\
\cline { 2 - 2 } & Compensation \\
\cline { 2 - 2 } & Contact \\
\hline
\end{tabular}

\subsection{Tahapan Penelitian}

Tahapan penelitian yang dituangkan dalam diagram alir dibawah ini, menggabarkan proses penelitian yang akan ditempuh sekaligus menggambarkan penelitian secara keseluruhan. Tahapan penelitian dapat dilihat dari Gambar Berikut.

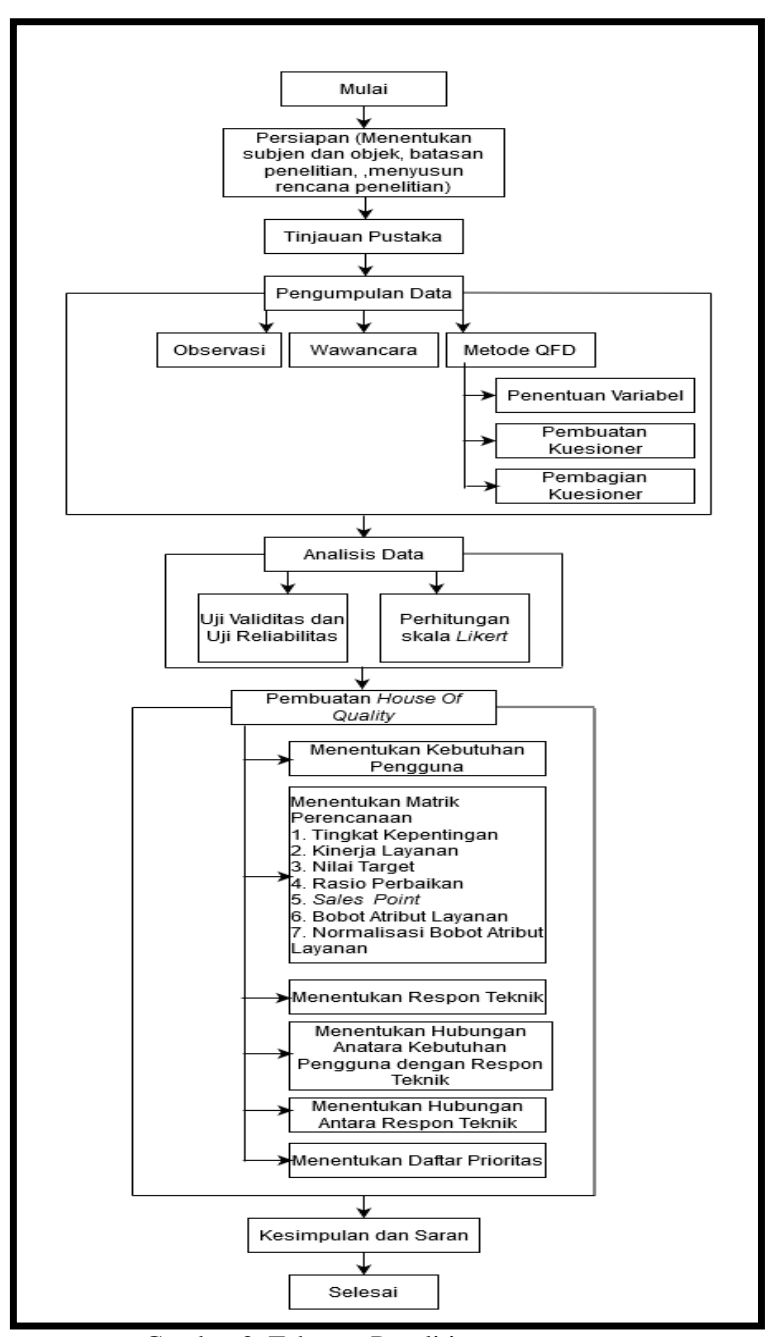

Gambar 3. Tahapan Penelitian 


\section{HASIL DAN PEMBAHASAN}

\subsection{Pembuatan House Of Quality}

Adapun tahapan-tahapan pembuatan House Of Quality adalah sebagai berikut:

1. Kebutuhan Pengguna

Kebutuhan pengguna didapat dari data atribut variabel parasuraman Service Quality [2] yang mengatakan Servqual dapat digunakan pada rumah kualitas untuk mengevaluasi layanan organisasi berdasarkan keinginan pelanggan.Seperti dicatat [6], dimensi Servqual dapat dimodifikasi berdasarkan persyaratan dan kebutuhan dari suatu organisasi. Hal ini dapat digunakan untuk mengidentifikasi dan menganalisisi keinginan konsumen dan dengan demikian membentuk tahap pertama dalam sebuah House OfQuality. yang bertujuan untuk memperoleh atribut layanan yang dibutuhkan oleh pengguna sistem knowledge management PT. Pupuk Sriwidjaja Palembang untuk menentukan atribut-atribut jasa dengan menyesuaikan atribut pada variabel, sehingga atribut-atribut sesuai dengan kebutuhan pengguna sistem.

\section{Matrik Perencanaan}

Perhitungan atau tahapan pada matrik perencanaan ada 7 perhitungan dengan rumusnya masing-masing tahapan pada matrik perencanaan dapat dilihat berikut:

1. Hasil Perhitungan Tingkat Kepentingan Relatif

Butir Atribut Layanan Ideal Harapan Sistem Knowledge Management (Importance to Customer)

Tingkat kepentingan digunakan untuk memposisikan setiap kebutuhan pengguna sistem untuk harapan kedepannya untuk pengembangan sistem dalam bentuk data kualitatif dengan tujuan untuk memprioritaskan kebutuhan pengguna Sistem Knowledge Management PT.Pupuk Sriwidjaja Palembang.

$$
\text { Tingkat Kepentingan }=\frac{\sum_{S}^{i} \operatorname{Sixi}}{N}
$$

Sebagai contoh perhitungan pada tingkat kepentingan relatif butir atribut layanan yang pertama dapat dilihat dengan perhitungan berikut:

Tingkat Kepentingan $=\frac{(1 \times 0)+(2 \times 8)+(3 \times 27)+(4 \times 100)+(5 \times 192)}{327}=\frac{1457}{327}=4,456$

2. Hasil Perhitungan Kinerja Atribut Layanan Sistem Knowledge Management (Customer Satisfaction Performance)

Kinerja atribut layanan sistem knowledge management dipandang dari sisi pengguna adalah menentukan nilai target oleh penyedia pihak layanan Departemen Pendidikan dan Pelatihan.

$$
\text { Tingkat Kepuasan }=\frac{\sum_{S}^{i} \text { Sixi }}{N}
$$

Sebagai contoh perhitungan pada kinerja atribut layanan untuk butir atribut layanan yang pertama, dengan nilai Si dapat dilihat pada table 4.5, yaitu:

Tingkat Kepuasan $=\frac{(1 \times 0)+(2 \times 26)+(3 \times 102)+(4 \times 109)+(5 \times 90)}{327}=\frac{1244}{327}=3,804$ hasil perhitungan menunjukan rata-rata hitung dari ke 33 atribut kinerja layanan menunjukan bahwa kualitas kinerja sistem knowledge management dapat dikategorikan berdasarkan menjadi beberapa kategori yang dapat dilihat pada tabel 3 berikut:

Tabel 3. Pengkategorian Nilai
\begin{tabular}{|c|c|c|}
\hline No. & Batasan Nilai & Kategori \\
\hline 1. & $0,00-0,199$ & Sangat rendah \\
\hline 2. & $0,20-0,399$ & Rendah \\
\hline 3. & $0,40-0,599$ & Sedang \\
\hline 4. & $0,60-0,799$ & Kuat \\
\hline 5. & $0,80-1,000$ & Sangat kuat \\
\hline
\end{tabular}

\section{Nilai Target (Goal)}

Nilai target ditentukan oleh pihah penyedia layanan sistem knowledge management setiap atribut layanan kinerja sistem knowledge management yang dinilai oleh pengguna layanan dapat dijadikan acuan untuk menetapkan nilai target untuk sistem knowledge management.

\section{Rasio Perbaikan (Improvement Ratio)}

Rasio perbaikan bertujuan untuk mengetahui nilai yang harus dicapai oleh penyedia layanan dalam hal ini pihak Departemen Pendidikan dan Pelatihan sebagai penyedia layanan.

$$
\begin{aligned}
& \text { Improvement Ratio }(i) \\
& =\frac{\text { Goal }(i)}{\text { Customer Satisfaction Performance }(i)} \\
& \quad=\frac{5}{3,804}=1,314
\end{aligned}
$$

\section{Titik Kepuasan (Sales Point)}

Sales point ditentukan oleh pihak penyedia layanan yaitu Departemnt Pendidikan dan Pelatihan berdasarkan pada setiap atribut yang dapat mempengaruhi pada nilai kualitas layanan sistem knowledge management.

Adapun nilai yang digunakan dalam sales poin yaitu:

Tabel 4. Pengkategorian Nilai
\begin{tabular}{|c|c|}
\hline Nilai & Keterangan \\
\hline 1 & Tanpa Titik Kepuasan \\
\hline 1,2 & Titik Kepuasan Menengah \\
\hline 1,5 & Titik Kepuasan Tinggi \\
\hline
\end{tabular}

6. Bobot Atribut Layanan Sistem Knowledge Management PT.Pupuk Sriwidjaja Palembang (Raw Weight)

Atribut layanan yang akan ditingkatkan dan dikembangkan perlu ditentukan bobot prioritas atribut layanan tersebut. Dengan mengetahui prioritas pengembangan atribut layanan, maka dapat ditentukan urutan atribut mana yang akan ditingkatkan dan dikembangkan. Bobot setiap atribut dihitung dengan rumus berikut:

Raw Weight $=$ Improtance to Customer $x$ Improvement Ratio $\times$ Sales Point

Sebagai contoh perhitungan bobot pada atribut layanan yang pertama yaitu: 


$$
\begin{aligned}
\text { Raw Weight } & =4,456 \times 1,314 \times 1,1,5 \\
& =8,783
\end{aligned}
$$

7. Normalisasi Bobot Atribut Layanan (Normalized Raw Weight)

Dari perhitungan bobot yang sudah diperoleh perlu dinormalisasikan.Menormalisasikan bobot bertujuan untuk memudahkan dalam menentukan prioritas pengembangan atribut mana yang perlu segera mendapat pengembangan.Normalisasi bobot dihitung dengan membagi bobot dengan total bobot.

$$
\begin{aligned}
\sum \text { Raw Weight } & =(8,783+8,499+8,932+8,688 \\
& +9,042+8,960+8,771+8,796 \\
& +8,698+9,067+8,803+8,758 \\
& +8,785+8,842+8,856+8,400 \\
& +8,750+8,713+8,555+8,725 \\
& +8,535+8,440+8,649+8,789 \\
& +8,702+8,816+8,671+8,656 \\
& +8,616+8,986+8,690+8,556 \\
& +8,877) \\
= & 288,408
\end{aligned}
$$

Contoh perhitungan normalisasi bobot untuk atribut layanan yang pertama sebagai berikut:

$$
\begin{aligned}
\text { Normalized Raw Weight } & =\frac{\text { Raw Weight }}{\text { Total Raw Weight }} \\
& =\frac{8,782}{288,408}=3,045
\end{aligned}
$$

\section{Respon Teknik}

Respon teknik merupakan hasil penerjemahan dari kebutuhan pengguna, dari kebutuhan diterjemahkan ke dalam bahasa teknik yang juga melihat dari nilai tingkat kepentingan dan kinerja layanan pada matrik perencanaan, yang dapat diukur untuk menentukan daftar prioritas yang akan dicapai dan untuk menentukan atribut mana yang nantinya akan dikembangkan terlebih dahulu dari respon teknik.

4. Hubungan Antara Kebutuhan Pengguna dengan Respon Teknik

Tahap ini dimaksudkan untuk mengetahui keeratan hubungan masing-masing komponen respon teknik dalam memenuhi kebutuhan pengguna.

Tipe-tipe Simbol hubungan yang digunakan adalah:

$$
\begin{aligned}
& (\mathbf{O}=\text { Hubungan Kuat }=9 \\
& \bigcirc=\text { Hubungan Sedang }=3 \\
& \Delta=\text { Hubungan Lemah }=1
\end{aligned}
$$

Nilai matrik hubungan untuk masing-masing atribut harus diketahui karena nilai dari matrik respon teknik akan dirangkingkan. Nilai ini dibedakan menjadi dua yaitu absolute importance dan relative importance. Absolute importance adalah suatu indikasi yang menunjukan kebutuhan pengguna yang harus dipenuhi dengan melihat hubungannya dengan respon teknik, absolute importance dapat diperoleh menggunakan rumus:

$$
\text { Absolute Importance } \left.=\sum \text { (Importance to Customer } x \text { Relationship Matrik }\right)
$$

[4] mengatakan nilainormalized raw weight $x$ relationship matrik nilai dari hasil ini disebut importance to customer $x$ relationship matrik. Adapun contoh perhitungan nilai respon teknik untuk atribut "Sistem Knowledge Management Mengupdate Informasi Setiap Hari Pada Sistem Knowledge Management" berikut:

Absolute Importance $=(3,045 \times 9)+(3,097 \times 3)$

$$
\begin{aligned}
& (3,012 \times 9)+(3,041 \times 9)+(3,016 \times \\
& 3)+(3,144 \times 9)+(3,037 \times 9)+ \\
& (3,046 \times 9)+(3,057 \times 3)
\end{aligned}
$$

$=192,435$

Untuk perhitungan tingkat kepentingan relatif dari respon teknik diperoleh bagi antara masing-masing respon teknik dengan jumlah total dari respon teknik, dengan rumus kepentingan relative berikut:

Relative Importance

$$
=\frac{\text { Absolute Importance }}{\sum \text { Absolute Importance }} \times 100 \%
$$

Adapun contoh perhitungan untuk mengetahui nilai kepentingan relatif, berikut:

Relative Importance $=\frac{192,435}{1,018,114}=18,901$

\section{Hubungan Antara Respon Teknik}

Untuk mengidentifikasi hubungan antara respon teknik perlu dilakukan untuk mengetahui adanya hubungan masing-masing atribut respon teknik tersebut. Tipe-tipe Simbol hubungan yang digunakan adalah:

$++=$ Hubungan Kuat Positif

$+=$ Hubungan Positif

-- = Hubungan Kuat Negatif

- = Hubungan Negatif

\section{Daftar Prioritas Kebutuhan Pengguna}

Daptar prioritas adalah merupakan tahapan terakhit dari pembuatan House Of Quality, yang didapat setelah menentukan respon teknik dan melakukan perhitungan pada matrik perencanaan dan penentuan hubungan antara kebutuhan pengguna dengan respon sehingga, hasil akhirnya yang didapat adalah daftar prioritas dari respon teknik yang harus dikembangkan terlebih dahulu untuk meningkatkan kualitas layanan sistem. 


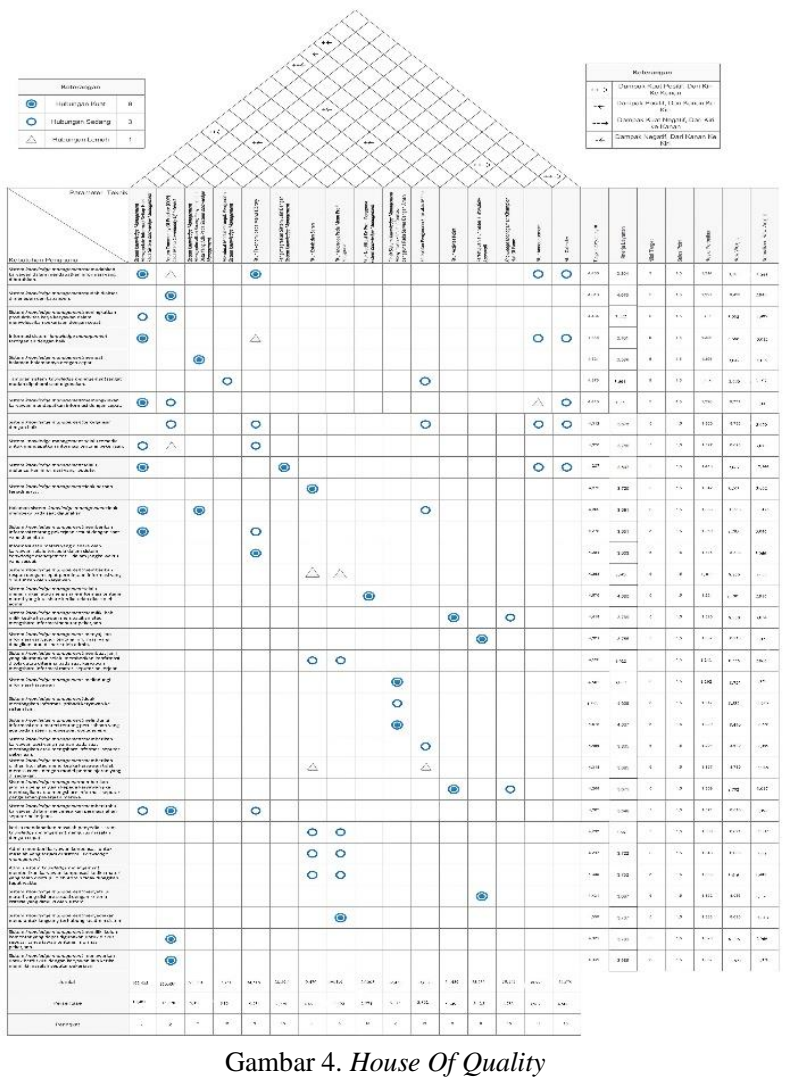

4.2 Pembahasan House Of Quality

Matriks $H O Q$ merupakan upaya suatu proses untuk mengkonversi voice of quality atau kebutuhan pengguna secara langsung terhadap respon teknik atau spesifikasi teknik dari sebuah penilaian yang dihasilkan dalam pembuatan house of quality.

1. Kinerja Atribut Layanan Sistem Knowledge Management PT.Pupuk Sriwidjaja Palembang

Kinerja atribut pada sistem knowledge management dilakukan penilaian berdasarkan jawaban oleh responden yang merupakan pengguna dari sistem knowledge management untuk mengukur tingkat kualitas layanan sistem knowledge management. Berdasarkan hasil keseluruhan dari jawaban responden berdasarkan atribut kebutuhan pengguna dengan skor rata-rata 3,764 yang menyatakan bahwa tingkat dari kualitas sistem knowledge management berada pada kategori lemah sehingga dapat disimpulkan bahwa pengguna masih belum sepuasnya merasakan tingkat dari kualitas layanan sistem knowledge management belum cukup baik dan mempengaruhi pengguna pada saat menggunakan sistem knowledge management.

\section{Penentuan Prioritas}

Penentuan prioritas merupakaan jawaban dari bagaiamana pihak layanan sistem knowledge management untuk meningkatkan kualitas layanan sistem knowledge management, cara meningkatkan kualitas layanan sistem knowledge management ialah dengan melihat nilai prioritas yang didapat dari hasil perhitungan pada tahapan pembuatan House Of Quality, terdapar 16 urutan daftar prioritas respon teknik yang harus dikembangkan sesuai dengan urutannya untuk menginkatkan kualitas layanan sistem Knowledge Management PT.Pupuk Sriwidjaja Palembang.

\section{KESIMPULAN}

Berdasarkan hasil dan pembahasan dari penelitian ini maka dapat disimpulkan sebagai berikut: Nilai ratarata kualitas layanan sistem knowledge management secara keseluruhan sesuai dengan nilai 3,764 dengan kategori lemah. Cara meningkatkan kualitas layanan sistem knowledge management PT.Pupuk Sriwidjaja Palembang ialah dengan melihat daftar prioritas yang harus dikembangkan terlebih dahulu dari respon teknik yang disusun berdasarkan kebutuhan pengguna sistem pada tahapan pembuatan House Of Quality, berikut merupakan 5 daftar prioritas sesuai dengan urutan daftar mana yang harus dikembangkan terlebih dahulu: Sistem knowledge management mengupdate informasi setiap hari pada sistem knowledge management, Forum community of practice (COP) pada menu community of interest, Fiutr taxonomi pada menu Library, Fitur kotak dan saran, Fitur Message pada menu profil pengguna.

\section{REFERENSI}

[1] Al Hakim, Taufiq Ismail. 2018. Analisis peningkatan kualitas layanan dengan menggunakan metode quality function deployment (QFD) (Studi kasus bus batik solo trans koridor 1). Dipublikasikan. Skripsi Institut Agama Islam Negeri Surakarta.

[2] Cudney, Elizabeth A. et. Al. 2011. Quality Function Deployment in Continuos Improvement. USA: Missouti University of Science and Technology.

[3] Dalkir, Kimiz. 2005. Knowledge Management in Theory and Ppractice. Oxford: Elsevier's Science \& Technology Rights Departement.

[4] Ficalora, Joseph p dan Louis Cohen. 2010. Quality function deployment and six sigma. Indiana : Internasional Sales.

[5] Mandasari, Nur Fitriayu. et. Al. 2015. Analysis knowledge management and strategic leadership dimensions on dynamic capability for successful strategy implementation in regional bank of sulserbar. Doctoral Student of Economics, Departement of Electrical Engineering, xxx, YYY. Vol. 5, No. 6, ISSN 2307-227X.

[6] Parasuraman, A. et. Al. 2005. E-S-QUAL A multiple-item scale for assessing electronic service quality. Journal of Service Research, Volume. 7 No. X, University of Miami.

[7] Polak. Przemyslaw. 2017. Employing the quality function deployment (QFD) method to support knowledge management in innovation process planning. University Of Techonology. Volume 5, Issue 2.

[8] Setiawan, Eman. Kualitas pelayanan akademik berbasis sistem informasi untuk kepuasan mahasiswa dengan menggunakan metode quality function deployment. Universitas Narotama.

[9] Subagiyo, Rokhmat \& Adlan, M. Aqim.2017. Pengaruh service quality, marketing mix dab 
kepuasan mahasiswa terhadap customer loyalty. IAIN Tulung agung. Jurnal ekonomi medornisasi, ISSN 0216-373X, ISSN 2502-4578.

[10] Sugiyono. 2017. Metode penelitian kuantitatif, kualitatif dan R\&D. Bandung : Alfabeta.

[11] Waltz, Edward. 2003.Knowledge management in the intelligence enterprise. Boston London : Artech House. 